Научная статья

УДК 338.48

DOI 10.18101/2304-4446-2021-1-62-71

\title{
ТУРИЗМ И ПАНДЕМИЯ COVID-19: ОПЫТ И УРОКИ РЕСПУБЛИКИ БУРЯТИЯ
}

\author{
(C) Максанова Людмила Бато-Жаргаловна \\ доктор экономических наук, доцент, старший научный сотрудник, \\ Байкальский институт природопользования СО РАН \\ Россия, 670047, г. Улан-Удэ, ул. Сахьяновой, 8 \\ lmaksanova@yandex.ru
}

\section{(C) Дугарова Туяна Борисовна}

заместитель министра,

Министерство туризма Республики Бурятия

Россия, 670000, г. Улан-Удэ, ул. Ербанова, 7

dugarova.T@Baikal.govrb.ru

\section{(C) Кауров Иван Александрович}

аспирант,

Байкальский институт природопользования СО РАН

Россия, 670047, г. Улан-Удэ, ул. Сахьяновой, 8

ivan.kaurov@inbox.ru

Аннотация. С момента распространения коронавирусной пандемии COVID-19 туризм и гостиничный бизнес в России включены в перечень наиболее пострадавших секторов экономики. Впервые в истории российского туризма реализуются беспрецедентные меры по поддержке отрасли. В дополнение к федеральному антикризисному пакету мер поддержки во многих российских регионах применяются разные способы помощи хозяйствующим субъектам. В данной статье отражен анализ развития туризма в Республике Бурятия в период распространения COVID-19. Рассматриваются задачи и мероприятия по снижению последствий кризиса и восстановлению туристической деятельности. Показано, как Республика Бурятия, используя новые подходы, совершенствует собственную региональную политику по поддержке, восстановлению и дальнейшему развитию сферы туризма. Результаты проведенного исследования могут быть использованы при формировании программных мер развития сферы туризма в постковидный период.

Ключевые слова: туризм; пандемия; COVID-19; антикризисные меры; государственная поддержка; Республика Бурятия.

\section{Для цитирования}

Максанова Л. Б.-Ж., Дугарова Т. Б., Кауров И. А. Туризм и пандемия COVID-19: опыт и уроки Республики Бурятия // Вестник Бурятского государственного университета. Экономика и менеджмент. 2021. № 1. С. 62-71.

Пандемия COVID-19 нанесла сокрушительный удар по туристической индустрии во всем мире. Очевидно, что драматические изменения на международном и внутреннем рынках туризма еще долго будут предметом изучения. Исследова- 

уроки Республики Бурятия

тели туризма изучают, как пандемия может изменить общество, экономику и туризм, сравнивают воздействие COVID-19 с предыдущими эпидемиями/пандемиями и другими типами глобальных кризисов ${ }^{1}$. Также оценивается глубина падения и величина потерь отрасли на глобальном и региональных рынках $^{2}$ [1], разрабатываются сценарные прогнозы объемов и темпов восстановления туристических потоков [2], предлагаются стратегические решения для преодоления кризиса в индустрии гостеприимства и различные способы восстановления туристского сектора ${ }^{3}$. В условиях пандемии неизбежно сформировались новые тренды в сфере туризма, которые повлияли и будут влиять на определение стратегических направлений процессов ее восстановления и дальнейшего развития ${ }^{4}$ [3]. Считается, что «стабильная потребность в путешествиях и новых впечатлениях снова поможет индустрии выйти из кризиса» ${ }^{5}$. Однако, по мнению ряда исследователей, восстановление индустрии туризма во всем мире займет больше времени, чем средний ожидаемый период восстановления, составляющий 10 месяцев, и чтобы ускорить этот процесс, необходимы эффективные планы действий в чрезвычайных ситуациях при координации усилий государственного и частного секторов [9]. В этом русле изучение опыта Республики Бурятия по противодействию распространению COVID-19 и внедрению антикризисных мер для поддержки туризма позволяет понять, какие уроки следует извлечь для будущего развития и на какие решения нужно опираться в долговременной перспективе.

Прежде всего укажем, что развитие туризма в Республике Бурятия в доковидный период характеризовалось положительной динамикой основных показателей (рис. 1 , 2). В отрасли работают 27 туроператоров, 65 турагентств, 14 санаторно-курортных организаций, 486 объектов размещения, из них 70 классифицированных.

\footnotetext{
${ }^{1}$ Gössling S., Scott D., Hall C. M. Pandemics, tourism and global change: A rapid assessment of COVID-19 Journal of Sustainable Tourism. 10.1080/09669582.2020.1758708; Uğur N. G., Akbiyık A. Impacts of COVID-19 on global tourism industry: A cross-regional comparison. Tourism Management Perspectives. 2020. Vol. 36. 100744.

${ }^{2}$ Hao F., Xiao Q., Chon K. COVID-19 and China's Hotel Industry: Impacts, a Disaster Management Framework, and Post-Pandemic Agenda // International Journal of Hospitality Management, Volume. 2020. Vol. 90. 102636.

${ }^{3}$ Kreiner N.C., Ram Y. National tourism strategies during the COVID-19 pandemic // Annals of Tourism Research. 2020. 103076.

${ }^{4}$ Агентство инноваций Москвы. Туризм. Прогноз развития отрасли после COVID-19. URL: https://ict.moscow/research/turizm-prognoz-razvitiia-otrasli-posle-covid-19/ (дата обращения: 15.12.2020). Текст: электронный.
}

${ }^{5}$ Там же. 


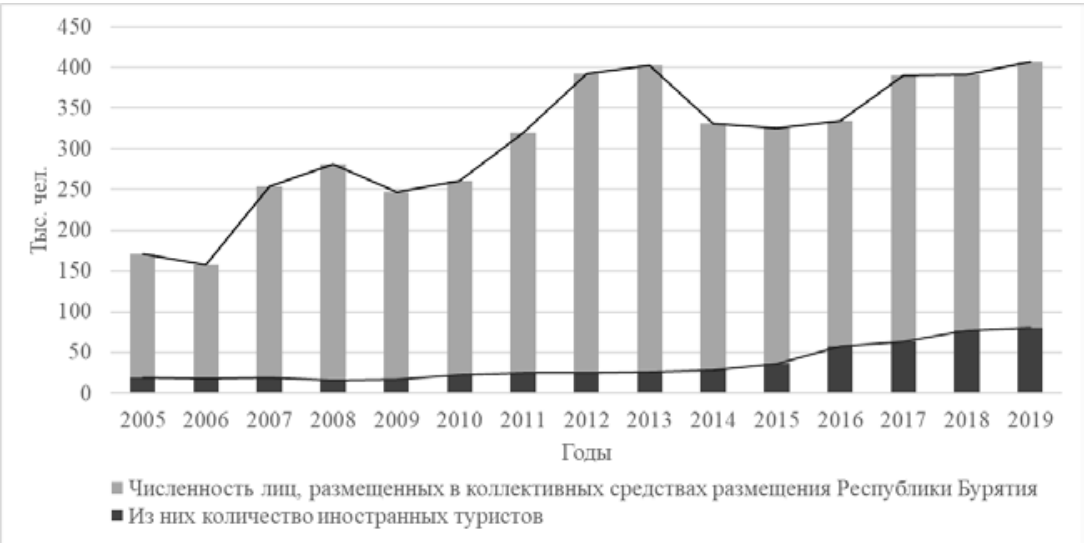

Рис. 1. Динамика численности лиц в коллективных средствах размещения в Республике Бурятия, 2005-2019 гг., тыс. чел.

Источник: составлено по данным ${ }^{1}$

Доля иностранных граждан в коллективных средствах размещения составила $12,2 \%$ (49,697 тыс. чел.). Согласно региональному мониторингу, объем иностранного турпотока колеблется в пределах 81 тыс. чел. По данным Управления Федеральной миграционной службы по Республике Бурятия, иностранные туристы прибывают в республику из 108 стран. В структуре въездного турпотока $30,2 \%$ занимают туристы из Монголии, 29,2\% - КНР, 9,7\% - Германии, 3,4\% - Франции, 3\% - Южной Кореи, 1,7\% - Великобритании, 1,5\% - Австралии, по 1,2\% - Японии, Италии, Польши.

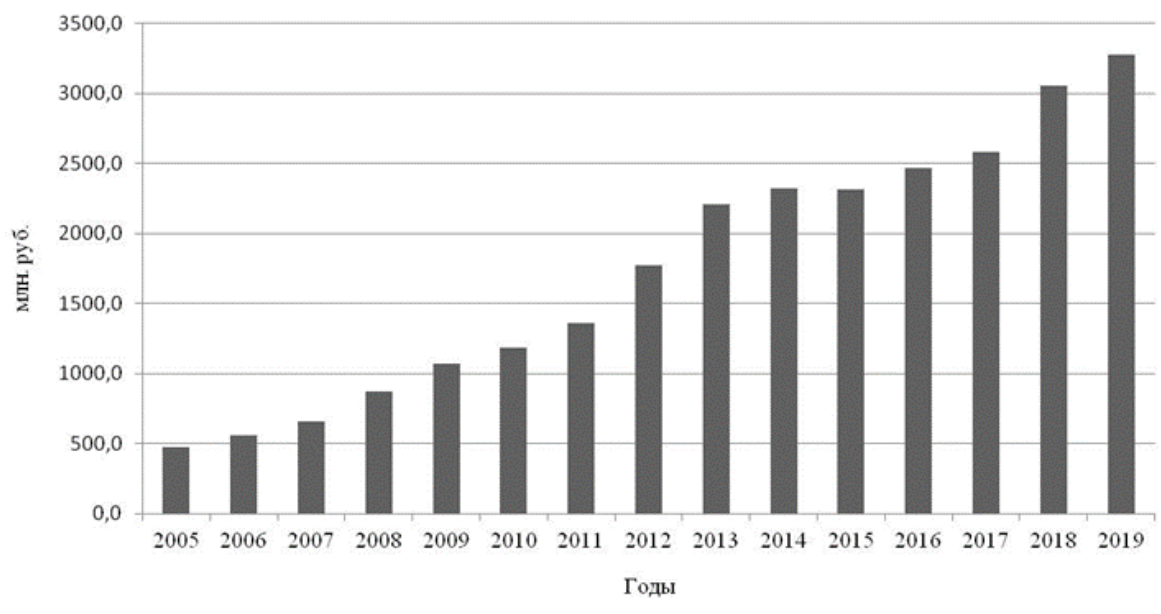

Рис. 2. Динамика объёма платных услуг, оказанных туристам, в Республике Бурятия, 2005-2019 гг., тыс. чел. Источник: составлено по данным ${ }^{2}$

1 Единая межведомственная информационная статистическая система. URL: https://www.fedstat.ru/indicator/31280 (дата обращения: 24.01.2021 г.). Текст: электронный. 2 Там же. 

уроки Республики Бурятия

В связи с распространением коронавирусной инфекции COVID-19 с февраля 2020 г. произошло резкое снижение въездного и внутреннего турпотока из-за массовой отмены туров, приостановки деятельности гостиниц и санаториев, полной отмены и переноса крупных событийных мероприятий. Соответственно, загрузка гостиниц и иных средств размещения в феврале 2020 г. уменьшилась к аналогичному периоду прошлого года в среднем на $31 \%$, в марте - $70 \%$, в апреле и мае - 95\% (работали только гостиницы, принимающие командированных лиц). На протяжении всего ковидного периода деятельность регионального правительства характеризуется принятием оперативных и нестандартных решений для смягчения последствий кризиса и возобновления предпринимательской деятельности в русле реализации общефедеральной политики борьбы с COVID-19 (рис. 3).

Следует отметить, что в соответствии с указом Президента Российской Федерации от 02.04.2020 г. № 239 главы регионов были наделены полномочиями самостоятельного установления вида режима ограничений на территории конкретного региона (на передвижение граждан, деятельность ряда организаций и т. п.) исходя из объективной ситуации распространения новой коронавирусной инфекции в конкретном регионе. Решения принимались и продолжают приниматься по принципу «здесь и сейчас», что требует колоссальной отдачи от управленческих кадров. Очевидно, что в будущем потребуется организация системной подготовки управленческих кадров, в том числе к работе в условиях неопределённости.

В контуре туристического сектора реализация антикризисной политики в Республике Бурятия охватывает решение следующих задач:

1) организация защиты здоровья населения и гостей республики;

2) мониторинг туристических компаний по количеству отправленных туристов из Республики Бурятия в иностранные государства и срокам выезда-въезда;

3) поддержка работников сферы туризма, внезапно потерявших доход;

4) оценка экономических потерь и разработка мер по сохранению потенциала туристической отрасли;

5) разработка первоочередных мер по восстановлению и дальнейшему развитию туризма в постковидный период;

6) разработка мероприятий для включения в национальный проект «Туризм и индустрия гостеприимства».

В совокупности комплекс мер, реализованных на региональном уровне, объединяет общефедеральные системные меры для субъектов малого и среднего предпринимательства и региональный отраслевой пакет мер для турбизнеса, которые фокусируются на снижении административного регулирования, мерах налогового стимулирования, прямой финансовой помощи, инфраструктурной, информационной, образовательной и методической формах поддержки (таблица 1). В принятии решений в региональном измерении учитывались данные мониторинга рисков для действующих организаций в сфере туризма, а также мониторинга финансово-экономической деятельности системообразующих предприятий региона (из сферы туризма в перечень таковых организаций включено 8 компаний). 


\section{Федеральный уровен}

Постановление Главного государственного санитарного врача РФ от 24 января 2020 г. № 2 «О дополнительных мероприятиях по недопущению завоза и распространения новой коронавирусной инфекции...

- Временные ограничения движения граждан КНР через пункты пропуска на отдельных участках государственной границы РФ с Монголией (Распоряжение ПРФ № 154-р от 31.01.2020).

\section{Региональный уровень}

\begin{tabular}{|c|c|}
\hline & - Региональны \\
\hline 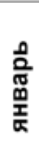 & $\begin{array}{l}\text { мероприятий. } \\
\text { - Мониторинг туроператоров и } \\
\text { турагентств по количеству отправленных } \\
\text { туристов из Республики Бурятия в } \\
\text { иностранные государства и срокам } \\
\text { выезда-въезда (январь-май). }\end{array}$ \\
\hline
\end{tabular}

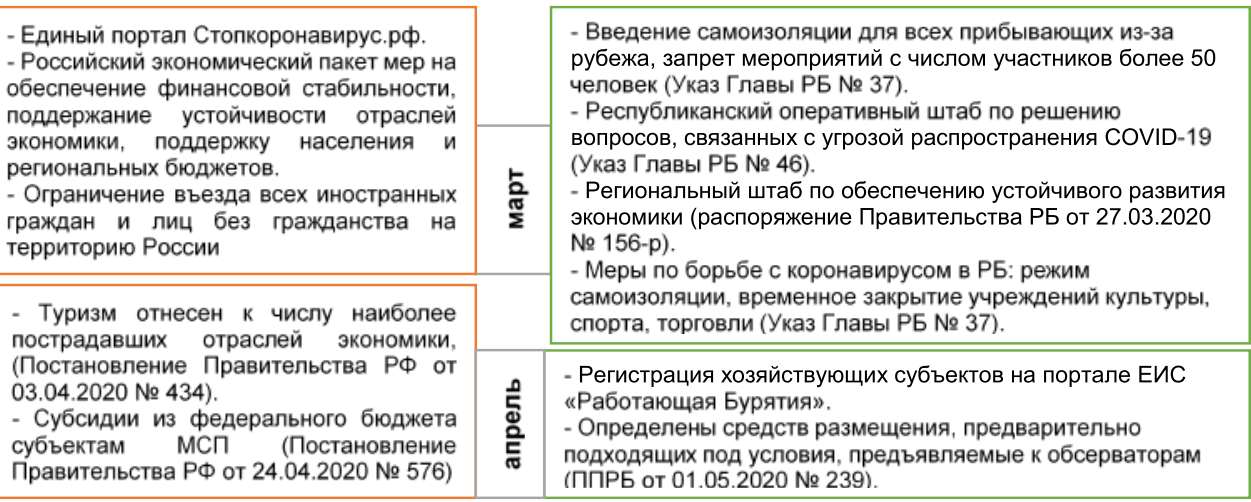

Рекомендации по профилактике - Совещания у Главы РБ А.С. Цыденова по открытию туристского новой коронавирусной инфекции сезона. (COVID-19) в учреждениях осуществляющих деятельность по предоставлению мест для временного проживания (гостиницы и иные средства размещения), утв. Главным Главным государственным
санитарным врачом РФ 26.05.2020.

- Порядок предоставления субсидий (ППРБ № 279, № 317) - Чат с предпринимателями с участием Роспотребнадзора и Министерства туризма по вопросам работы средств размещения. - Туристский личный кабинет модуля «Ковид» республиканской

s. государственной системы «Единая региональная интеграционная платформа аппаратно-программного комплекса «Безопасный гмород"

Рекомендации по профилактике - Возобновление деятельности санаторно-курортных организаций новой коронавирусной инфекции (COVID-19) в учреждениях осуществляющих деятельность по предоставлению мест для временного проживания (гостиницы и иные средства размещения), утв. Главным государственным санитарным врачом РФ 26.05.2020. и средств размещения для жителей РБ,

- Совещания по летнему туристскому сезону 2020 года под председательством Главы Республики Бурятия А.С. Цыденова. - Порядок оперативного реагирования в случае выявления лиц с

f COVID-19 (с подозрением) в учреждениях гостиничной и

호 туристической сферы.

- Введение новых направлений возмещения затрат субъектам МСП.

Правила предоставления в 2020 году из федерального бюджета субсидий субъектам МСП и о $\begin{array}{lr}\text { социально } & \text { ориентированным } \\ \text { некоммерческим } & \text { организациям }\end{array}$ некоммерческим организациям
(Постановление Правительства РФ от 02.07.2020 № 976)

- Возобновление деятельности санаторно-курортных организаций и средств размещения для жителей других регионов России. - Запуск чартерной программы TUI Россия в Республику Бурятия.

. - Порядок предоставления субсидий (ППРБ № 416, № 422)

오 - Проведение учений и обучающих семинаров по действиям в случае выявления лиц с COVID-19 (с подозрением) на объектах туризма.

\begin{tabular}{|c||c|}
\hline октябрь & $\begin{array}{l}\text { - Порядок предоставления субсидий из республиканского } \\
\text { бюджета (ППРБ № 639, № 740). }\end{array}$ \\
\hline $\begin{array}{c}\text { май- } \\
\text { декабрь }\end{array}$ & $\begin{array}{l}\text { Предоставление субсидий из республиканского бюджета в } \\
\text { соответствии с действующими порядками }\end{array}$ \\
\hline
\end{tabular}

Рис. 3. Основные события и мероприятия по противодействию COVID-19 и поддержке субъектов туристической деятельности в Республике Бурятия Источник: составлено авторами 
Л. Б.-Ж. Максанова, Т. Б. Дугарова, И. А. Кауров. Туризм и пандемия COVID-19: опыт и уроки Республики Бурятия

Таблица 1

Направления и меры государственной поддержки сферы туризма в Республике Бурятия в период распространения COVID-19

\begin{tabular}{|c|c|c|}
\hline \multirow[t]{2}{*}{$\begin{array}{l}\text { Направления } \\
\text { поддержки }\end{array}$} & \multicolumn{2}{|c|}{$\begin{array}{c}\text { Смягчение последствий кризиса } \\
\text { и стимулирование восстановления отрасли }\end{array}$} \\
\hline & $P \Phi$ & РБ \\
\hline $\begin{array}{l}\text { Снижение } \\
\text { административной } \\
\text { нагрузки }\end{array}$ & $\begin{array}{l}\text { Запрет на проверки, взыскания } \\
\text { и санкции со стороны ФНС и } \\
\text { других органов. } \\
\text { Мораторий на налоговые санк- } \\
\text { ции. } \\
\text { Запрет на возбуждение дел о } \\
\text { банкротстве. } \\
\text { Продление срока предоставле- } \\
\text { ния отчетности. } \\
\text { Предоставление судебной от- } \\
\text { срочки. } \\
\text { Послабления в лицензировании } \\
\text { и иных разрешительных проце- } \\
\text { дурах }\end{array}$ & $\begin{array}{l}\text { Отмена проверок. } \\
\text { Отсрочка введения Правил ор- } \\
\text { ганизации туризма и отдыха в } \\
\text { центральной экономической } \\
\text { зоне Байкальской природной } \\
\text { территории до конца } 2020 \text { г. }\end{array}$ \\
\hline $\begin{array}{l}\text { Меры } \\
\text { налогового } \\
\text { стимулирования }\end{array}$ & $\begin{array}{l}\text { Налоговые льготы. } \\
\text { Отсрочка по налогам } \\
\text { и страховым платежам }\end{array}$ & $\begin{array}{l}\text { Продление сроков уплаты рес- } \\
\text { публиканских и местных нало- } \\
\text { гов (авансовых платежей). } \\
\text { Снижение налога на недвижи- } \\
\text { мое имущество на } 2020 \text { год. } \\
\text { Уменьшение на } 90 \% \text { потенци- } \\
\text { ально возможного дохода для } \\
\text { расчета налога по патентной } \\
\text { системе налогообложения. } \\
\text { Введение режима самозанятых. } \\
\text { Освобождение от уплаты пла- } \\
\text { тежей субъектов Мсп - арен- } \\
\text { даторов государственного иму- } \\
\text { щества Республики Бурятия }\end{array}$ \\
\hline $\begin{array}{l}\text { Финансовые } \\
\text { меры поддержки }\end{array}$ & $\begin{array}{l}\text { Кредитная программа поддерж- } \\
\text { ки занятости (беспроцентные } \\
\text { кредиты на выплату зарплат). } \\
\text { Отсрочка по кредиту. Реструкту- } \\
\text { ризация кредитов. } \\
\text { Прямая безвозмездная финан- } \\
\text { совая поддержка (субсидии): } \\
\text { - на оплату труда работников } \\
\text { (370 СMП); } \\
\text { - на профилактику COVID-19 } \\
\text { (172 СMP). } \\
\text { Гранты Ростуризма (17 CMП на } \\
\text { сумму 47,8 млн р.) }\end{array}$ & $\begin{array}{l}\text { Субсидии на возмещение за- } \\
\text { трат: } \\
\text { - туроператорам на аренду по- } \\
\text { мещения (13 ТО); } \\
\text { - КСР на оплату коммунальных } \\
\text { услуг (49 КСР, работающих круг- } \\
\text { логодично); } \\
\text { - предприятиям санаторно- } \\
\text { курортной сферы (2); } \\
\text { - } 12 \text { направлениям (50 СМП) } \\
\text { Стимулирование создания без- } \\
\text { работными гражданами, от- } \\
\text { крывшими собственное дело, }\end{array}$ \\
\hline
\end{tabular}




\begin{tabular}{|l|l|l|}
\hline & & $\begin{array}{l}\text { дополнительных рабочих мест. } \\
\text { Содействие самозанятости без- } \\
\text { работных граждан }\end{array}$ \\
\hline $\begin{array}{l}\text { Инфраструктурная } \\
\text { поддержка }\end{array}$ & $\begin{array}{l}\text { Софинансирование реконструк- } \\
\text { ции автомобильной дороги в } \\
\text { рамках ТРК «На Великом чайном } \\
\text { пути» }\end{array}$ & $\begin{array}{l}\text { Софинансирование реконструк- } \\
\text { ции автомобильной дороги в } \\
\text { рамках TPК «На Великом чайном } \\
\text { пути» }\end{array}$ \\
\hline $\begin{array}{l}\text { Информационная } \\
\text { поддержка }\end{array}$ & $\begin{array}{l}\text { Онлайн-информирование по } \\
\text { программе «Поддержка в усло- } \\
\text { виях СОVID-19» }\end{array}$ & $\begin{array}{l}\text { Оперативное информирование } \\
\text { (сайт, чаты, СМИ и др.) }\end{array}$ \\
\hline Методическая & $\begin{array}{l}\text { Консультации по теме форс- } \\
\text { мажора }\end{array}$ & $\begin{array}{l}\text { Организационно-методическое } \\
\text { сопровождение соблюдения } \\
\text { карантинных мер }\end{array}$ \\
\hline Образовательная & $\begin{array}{l}\text { Акселератор по созданию ту- } \\
\text { ристско-рекреационных класте- } \\
\text { ров на охраняемых природных } \\
\text { территориях }\end{array}$ & $\begin{array}{l}\text { Туракселератор (бесплатный } \\
\text { образовательный интенсив) } \\
\text { курсы экскурсоводов }\end{array}$ \\
\hline
\end{tabular}

Источник: составлено по данным Министерства туризма Республики Бурятия

Обязательным условием получения государственной поддержки является регистрация субъекта туристической деятельности на сайте «Работающая Бурятия» по отраслевым ОКВЭД $(55,79,86.90 .4)$. Данная мера позволила в некоторой степени упорядочить учет хозяйствующих субъектов в сфере туризма, о чем свидетельствуют данные, представленные в таблице 2. Отметим, что потери на рынке туризма Бурятии в ковидных условиях составляют 2,3\% предприятий сферы туризма.

Таблица 2

Количество субъектов туристической деятельности

в Едином реестре субъектов малого и среднего предпринимательства

\begin{tabular}{|c|c|c|c|c|}
\hline \multirow{2}{*}{ Отраслевой ОКвЭД } & \multicolumn{4}{|c|}{ Количество субъектов туристической деятельности } \\
\cline { 2 - 5 } & на 10.01.2020 & на 10.03.2020 & на 10.09.2020 & на 10.01.2021 \\
\hline 55 & 312 & 271 & 299 & 303 \\
\hline 79 & 243 & 214 & 235 & 238 \\
\hline 86.90 .4 & 12 & 10 & 13 & 13 \\
\hline ИтОГО & 567 & 495 & 547 & 554 \\
\hline
\end{tabular}

Источник: составлено по данным Министерства туризма Республики Бурятия

В рамках возобновления деятельности санаторно-курортных организаций и средств размещения допуск к работе получило около $52 \%$ организаций, которые обеспечили соблюдение санитарно-противоэпидемических мер. В целях оперативного информирования бизнеса о принимаемых профилактических мерах был создан совместный чат с предпринимателями гостиничной сферы, профильного министерства, Роспотребнадзора, муниципальных образований, что позволило в режиме реального времени решать острые вопросы. Впервые региональный Роспотребнадзор действовал по принципу «лучше упредить нарушение, чем потом наказать». Востребованным инструментом стал туристический личный кабинет модуля «Ковид» рес- 
публиканской государственной системы «Единая региональная интеграционная платформа аппаратно-программного комплекса “Безопасный город”», который позволял определять статус потенциального клиента при его заселении в гостиницы и санатории (больной, контактный). Очевидно, что в целях совершенствования управления в сфере туризма представляется важным внедрение лучших практик применения нестандартных решений в цифровом формате.

Одним из перспективных инструментов развития в ковидный период стал запуск чартерных туристических программ из Москвы в Республику Бурятия при поддержке Ростуризма и регионального правительства. Здесь предусмотрено предоставление субсидий туроператорам Бурятии на возмещение части затрат на организацию групповых туристических поездок. И впервые в истории регионального туризма с 4 июля по 14 сентября 2020 г. компания TUI Россия реализовала 10 чартерных рейсов, обслужив 1528 туристов. Оценка удовлетворенности программой и обслуживанием в Республике Бурятия составила 4,8 из 5.

Также к числу нестандартных инициатив российского правительства по поддержке турбизнеса и создания условий для отдыха граждан страны относится выделение 15 млрд р. на программу стимулирования внутреннего туризма (Cash Back), в рамках которой граждане смогут получить возврат средств в пределах до 20 тыс. р. в зависимости от стоимости тура и периода его организации. В перспективе планируется расширение чартерных туристических программ в Республику Бурятия и содействие реализации программы Cash Back.

В ковидных условиях потребовалось существенное расширение перечня мер государственной поддержки из республиканского бюджета, что осуществлялось согласно действующему порядку финансовой помощи (i), а также в рамках формирования дополнительных мер (ii):

(i) Финансовая поддержка согласно постановлению Правительства Республики Бурятия от 07.12.2009 г. № 453 оказана 50 предпринимателям на сумму 15157,0 тыс. p. в значительной степени на возмещение затрат, связанных с приобретением рециркуляторов, озонаторов, бактерицидных ламп, применяемых для проведения дезинфекции помещений, а также бесконтактных термометров;

(ii) В целях реализации дополнительных мер поддержки утвержден порядок предоставления новых видов субсидий, что позволило обеспечить сохранение численности работников и продолжение деятельности туристических предприятий (таблица 3). Во многом благодаря вышеуказанным мерам в 64 организациях, получивших поддержку, удалось обеспечить занятость 1222 чел., или 108,8\%, на 1 марта 2020 г.

В целом совокупный объем адресной финансовой государственной поддержки организаций туристической отрасли из республиканского бюджета в 2020 г. составил 52,3 млн р., что в 21,5 раза больше, чем в 2019 г.

Анализ предварительных результатов работы отрасли туризма в Республике Бурятия в ковидный период по итогам 10 месяцев 2020 г. позволяет отметить существенное влияние общесистемных мер государственной поддержки в части сохранения совокупного потенциала отрасли. К положительным результатам следует отнести сохранение численности работников, что косвенно подтверждается приростом налога на доходы физических лиц (8\%) по виду деятельности 55.1 «Деятельность гостиниц и прочих мест для временного проживания» за 
11 месяцев 2020 г. по отношению к аналогичному периоду 2019 г. Вместе с тем, как и ожидалось, функционирование туристических предприятий отрасли в условиях высокой неопределенности повлекло потерю доходов отрасли. Так, по данным Бурятстата, объем платных услуг за 10 месяцев 2020 г. снизился по отношению к аналогичному периоду прошлого года на $37,07 \%$, составив 1735,0 млн р. В то же время объем платных услуг коллективных средств размещения в июле 2020 г. превысил значение июля 2019 г. на 7,3\%, что демонстрирует обоснованность и своевременность региональной политики по смягчению последствий кризиса и стимулированию восстановления туристических потоков.

Таблица 3

Дополнительные меры государственной поддержки (в виде субсидий), оказываемые субъектам туристической деятельности в Республике Бурятия в период распространения коронавирусной инфекции

\begin{tabular}{|l|c|c|c|c|}
\hline \multicolumn{1}{|c|}{ Наименование субсидии } & \multirow{2}{*}{$\begin{array}{c}\text { Количество } \\
\text { получателей }\end{array}$} & $\begin{array}{c}\text { Сумма, } \\
\text { тыс. } .\end{array}$ & \multicolumn{2}{|c|}{ Количество работников } \\
\cline { 4 - 5 } & субсидии & & 01.03 .2020 & 01.11 .2020 \\
\hline $\begin{array}{l}\text { Субсидия туроператорам на аренду } \\
\text { нежилых помещений (офисов) }\end{array}$ & 13 & 417,6 & 42 & 55 \\
\hline $\begin{array}{l}\text { Субсидия на оплату коммунальных } \\
\text { услуг средствам размещения, } \\
\text { работающим круглогодично }\end{array}$ & 49 & 9430,8 & 633 & 699 \\
\hline $\begin{array}{l}\text { Субсидия санаторно-курортным } \\
\text { организациям }\end{array}$ & 2 & 24422,8 & 448 & 468 \\
\hline Всего & 64 & 34271,2 & 1123 & 1222 \\
\hline
\end{tabular}

Источник: составлено по данным Министерства туризма Республики Бурятия

Таким образом, рассмотренный опыт развития туризма в Республике Бурятия в условиях пандемии свидетельствует о том, что выход сферы туризма из глубочайшего кризиса зависит от способности быстрой адаптации к новой слабопредсказуемой реальности, формирования алгоритмов оперативных и слаженных действий по противодействию распространению COVID-19, поиска и использования неспецифичных инструментов поддержки хозяйствующих субъектов с учетом имеющихся финансовых и организационно-управленческих возможностей. Авторы убеждены, что для формирования мер поддержки будущего развития отрасли необходимы дополнительные детальные и достоверные сведения о последствиях COVID-ограничений на условия и перспективы развития туристических предприятий, что предполагает проведение дополнительных исследований.

Благодарность

Работа выполнена в рамках государственного задания БИП СО РАН № АAАA-А21121011590039-6

\section{Литература}

1. Жуковская И. Ф., Овчинников А. Ю. Туризм и COVID-19: анализ проблем и перспективы развития после пандемии // Вестник Национальной академии туризма. 2020. № 3(55). C. 24-27. 

уроки Республики Бурятия

2. Zaborovskaia O., Sharafanova E., Maksanova L. Scenario Forecasting Tourist Flows during the COVID-2019 Pandemic // International Journal of Technology. 2020. № 11(8). P. 1570-1578.

3. Максанова Л. Б.-Ж., Андреева А. М. Развитие туризма в условиях пандемии: новые тренды и антикризисные меры // Общество: политика, экономика, право. 2020. № 12. С. 64-68.

Статья поступила в редакиию 25.01.2020; одобрена после рецензирования 28.01.2021; принята к публикаџии 29.01.2021.

\section{TOURISM AND COVID-19 PANDEMIC: EXPERIENCE OF THE REPUBLIC OF BURYATIA}

Lyudmila B.-Zh. Maksanova

Dr. Sci. (Econ.), A/Prof., Senior Researcher, Baikal Institute of Nature Management SB RAS 8 Sakhyanovoy St., Ulan-Ude 670047, Russia lmaksanova@yandex.ru

Tuyana B. Dugarova

Deputy Minister,

Ministry of Tourism of the Republic of Buryatia

7 Erbanova St., Ulan-Ude 670000, Russia

dugarova.t@baikal.govrb.ru

\section{Ivan A. Kaurov}

Research Assistant, Baikal Institute of Nature Management SB RAS 8 Sakhyanovoy St., Ulan-Ude 670047, Russia ivan.kaurov@inbox.ru

Abstract. With the spread of corona virus disease tourism and hotel industry in Russia have been included in the list of the most affected economy sectors. For the first time in the history of Russian tourism, the government implemented unprecedented efforts to support the sector. In addition to the federal anti-crisis support measures, many Russian regions employ different methods of assistance to economic entities.

The article analyzes the development of tourism in the Republic of Buryatia in a pandemic. We have considered the tasks and measures to reduce the consequences of the crisis and restore tourist activity. Today, the Republic of Buryatia use new approaches for the improvement of its own regional policy to support, restore and develop the tourism sector. The research results can be used in working-out the program measures for the development of tourism in the post Covid period.

Keywords: tourism; pandemic; COVID-19; anti-crisis measures; government support; the Republic of Buryatia. 